\begin{tabular}{c|c|c}
\hline \hline Vol. 260: 19-31, 2003 & MARINE ECOLOGY PROGRESS SERIES \\
Mar Ecol Prog Ser & Published September 30 \\
\hline \hline
\end{tabular}

\title{
Effects of high pH on a natural marine planktonic community
}

\author{
Maria Fenger Pedersen, Per Juel Hansen* \\ Marine Biological Laboratory, University of Copenhagen, Strandpromenaden 5, 3000 Helsingør, Denmark
}

\begin{abstract}
A natural planktonic community was incubated for 2 wk to study its response to different levels of $\mathrm{pH}$, ranging from 8 to 9.5. A general increase in phytoplankton biomass was observed over time in the $\mathrm{pH} 8$ to 9 incubations. In the $\mathrm{pH} 9.5$ incubation, the phytoplankton biomass decreased close to detection limit during the first week; however, at the termination of the experiment, the initial biomass level was regained. In the $\mathrm{pH} 8$ and 8.5 incubations, the diatoms Cerataulina pelagica, Cylindrotheca closterium and Leptocylindrus minimus became numerous, whereas in the pH 9 and 9.5 incubations, C. closterium solely made up the diatom biomass at the termination of the experiment. Photosynthetic dinoflagellates of the genus Ceratium, which were initially abundant, did not grow well in any of the incubations, probably due to the low nutrient concentrations. The protozooplankton biomass increased over time in the $\mathrm{pH} 8$ to 9 incubations. In the $\mathrm{pH} 9.5$ incubation, the protozooplankton biomass decreased close to detection limit during the first $3 \mathrm{~d}$ of the experiment and stayed at that level until the termination of the experiment. The biomass increase found in the $\mathrm{pH} 8$ to 9 incubations was due to an increase in the number of ciliates, because the heterotrophic dinoflagellate number remained almost constant. Most protozooplankton species incubated at $\mathrm{pH} 9.5$ died; however, the ciliate Myrionecta rubra survived at almost the same cell number as in the lower $\mathrm{pH}$ incubations. Overall a species succession occurred among both phototrophic and heterotrophic protists when $\mathrm{pH}$ approached 9. In the $\mathrm{pH} 9.5$ incubation, the number of different protist taxa was reduced from 34 at the start of the experiment to 10 at the termination of the experiment. In conclusion, our study indicates that elevated $\mathrm{pH}(>9)$ in nature will affect the entire plankton community mainly by reducing the species richness and by favouring algal blooms due to loss of grazing.
\end{abstract}

KEY WORDS: High pH · Planktonic protists $\cdot$ Ciliates $\cdot$ Diatoms $\cdot$ Dinoflagellates $\cdot$ Cylindrotheca closterium · Copepods

Resale or republication not permitted without written consent of the publisher

\section{INTRODUCTION}

Marine waters have traditionally been considered a $\mathrm{pH}$-stable environment with a $\mathrm{pH}$ value of $8 \pm 0.5$, due to the high buffer capacity found here (e.g. Hinga 1992, 2002). This point of view is exemplified by a quote from Barker (1935b) who wrote: 'Dinoflagellates are by no means as sensitive to small changes in $\mathrm{pH}$ as expected for organisms accustomed to such constant an environment as the ocean'. Consequently, effects of high $\mathrm{pH}$ on marine planktonic protists are not well documented; especially studies of the effects of high $\mathrm{pH}$ on heterotrophic protists are sparse. This is in contrast to freshwater ecology where the influence of $\mathrm{pH}$ as a forcing factor has been considered for decades. Models for estimating lake $\mathrm{pH}$ on the basis of the $\mathrm{pH}$ optima of the diatom species present in the lake even have been made (ter Braak \& van Dam 1989).

The view of the marine environment as constant with respect to $\mathrm{pH}$ fluctuations has changed recently. This is mainly due to the anthropogenic nutrient enrichment of many coastal areas, causing phytoplankton blooms, and thereby high $\mathrm{pH}$ values in places like bays, lagoons, salt ponds and tidal pools (e.g. Droop 1959, Santhanam 1994, Macedo et al. 2001). The bestinvestigated location in Denmark where high $\mathrm{pH}$ is found is Mariager Fjord. During the last $10 \mathrm{yr}$, the average $\mathrm{pH}$ value during summers has been 8.8 , but during 
calm sunny periods, $\mathrm{pH}$ values up to 9.75 have been measured (Hansen 2002). However, equivalent values have been recorded in marine pools and smaller increases in $\mathrm{pH}$ have been measured in the surface waters of the North Sea, where during a Phaeocystis bloom $\mathrm{pH}$ increased from 7.9 to 8.7 (Brussaard et al. 1996). The duration of elevated $\mathrm{pH}$ is quite variable; in a Portuguese coastal lagoon, $\mathrm{pH}$ values above 8.5 are found all year round, whereas in rock pools and sediments, the $\mathrm{pH}$ can increase to 10 , but only lasts for days or hours (Gnaiger et al. 1978, Macedo et al. 2001).

An increase in $\mathrm{pH}$ in the marine environment, as in freshwater, is expected to cause a change in the planktonic protist composition. The most common marine phytoplankton species found to co-occur with high $\mathrm{pH}$ in nature are the dinoflagellates Heterocapsa triquetra, Prorocentrum minimum and P. micans, and the diatom Skeletonema costatum (Macedo et al. 2001, Hansen 2002). However, many different taxa of marine phytoplankton are found to grow at high $\mathrm{pH}$. Growth experiments with monocultures in the laboratory have shown that some cryptophytes, diatoms, dinoflagellates and prymnesiophyte species can grow at $\mathrm{pH}$ above 9, and a few species even above pH 10 (Goldman et al. 1982, Nimer et al. 1994, Elzenga et al. 2000, Schmidt \& Hansen 2001, Hansen 2002).

The knowledge of how heterotrophic organisms respond to high $\mathrm{pH}$ is very sparse. While nothing is known about how copepods are affected by high $\mathrm{pH}$, we have some knowledge of the response of protozooplankton to high pH. Droop (1959) found that the heterotrophic dinoflagellate Oxyrrhis marina is highly pH-tolerant. (Pedersen \& Hansen 2003, this issue) studied the effect of high $\mathrm{pH}$ on 4 ciliates and 2 heterotrophic dinoflagellates in laboratory cultures, and found that while some species are highly $\mathrm{pH}$-tolerant, others are quite sensitive to elevated $\mathrm{pH}$ and cannot survive at $\mathrm{pH}$ exceeding 8.9 .

Due to this very limited knowledge of the effects of high $\mathrm{pH}$ on the marine plankton organisms, the aim of this paper was to monitor the response of a natural planktonic community $(>15 \mu \mathrm{m})$ to different levels of $\mathrm{pH}$, thereby evaluating the effect of high $\mathrm{pH}$ on the species succession and diversity of both phototrophic and heterotrophic protists. Because nutrient limitation may affect the succession of protists, this was also taken into account.

\section{MATERIALS AND METHODS}

Water samples were collected from the pycnocline (water depth of $20 \mathrm{~m}$ ) at a station located in the Øresund, Denmark, on August 25, 2000. The water (salinity $22 \mathrm{psu}$ ) was collected using a Niskin water sampler, im- mediately filtered through a $160 \mu \mathrm{m}$ filter to remove large zooplankters and stored in a $25 \mathrm{l}$ container. The container was brought back to the laboratory and the water was poured into 4 clear 2.81 Nalgene $^{\circledR}$ bottles (\#1 to 4). The $\mathrm{pH}$ was elevated from the original 7.95 to 8.0 (\#1), 8.5 (\#2), 9.0 (\#3) and 9.5 (\#4) by addition of 0.1 and $1 \mathrm{M} \mathrm{NaOH}$. For $\mathrm{pH}$ measurements, a Sentron ${ }^{\circledR}$ $2001 \mathrm{pH}$ meter with a Red Line electrode, sensitivity 0.01 , and a 2 point calibration was used. To minimise the shock effects of high $\mathrm{pH}$, the $\mathrm{pH}$ was raised by levels of 0.5 units at $12 \mathrm{~h}$ intervals until the final value was reached. The bottles were mounted on a plankton wheel $(1 \mathrm{rpm})$ and incubated for $14 \mathrm{~d}$ at $15 \pm 1^{\circ} \mathrm{C}$ on a 16:8 h light:dark cycle at an irradiance of $50 \mu \mathrm{E} \mathrm{m}^{-2} \mathrm{~s}^{-1}$. The first sampling was carried out after $24 h_{\text {; }}$ subsequent samplings were done every second or third day during the next $14 \mathrm{~d}$.

At each sampling occasion, the temperature and $\mathrm{pH}$ were monitored and the $\mathrm{pH}$ adjusted. A total water volume of $300 \mathrm{ml}$ was removed; the water was used for nutrient $(3 \times 30 \mathrm{ml})$ and chlorophyll $a$ analyses $\left(\mathrm{chl} a_{i}\right.$ 65 to $95 \mathrm{ml}$ ) as well as enumeration and identification of protists and copepods (105 to $135 \mathrm{ml}$ was fixed in acidic Lugol's iodine [final concentration $1 \%$ ] and kept in the dark and cold until examination). After sampling, the bottles were refilled with GF/C-filtered seawater (taken at the same location and time as the experimental water) and adjusted to the given $\mathrm{pH}$, within $\mathrm{pH} 0.01$ of the given value, before they were remounted on the plankton wheel.

Inorganic nutrients $\left(\mathrm{NO}_{3}{ }^{-}, \mathrm{NO}_{2}^{-}, \mathrm{NH}_{4}{ }^{+}, \mathrm{PO}_{4}{ }^{2-}, \mathrm{SiO}_{4}{ }^{-}\right)$ were analysed at the National Environmental Research Institute, Roskilde, Denmark (Grasshoff 1976). Chl a was measured in triplicate by filtration of 20 to $30 \mathrm{ml}$ samples onto GF/C filters immediately after sampling. Filters were then extracted in $96 \%$ ethanol in the freezer overnight, and the next day centrifuged at $1000 \times g$ for $5 \mathrm{~min}$ before the fluorescence of the supernatant was measured with a Turner, TD-700 Laboratory Fluorometer.

Lugol-fixed samples for enumeration of protists were, depending on cell concentrations, poured in triplicates into 10 or $25 \mathrm{ml}$ sedimentation chambers. The dominant taxa (species or groups of species) were identified and enumerated using an inverted Olympus ${ }^{\circledast}$ microscope at a magnification of 100 to $400 \times$, thereby focussing on protists $>15 \mu \mathrm{m}$. Diatoms, dinoflagellates and ciliates dominated the samples and were identified using Dodge (1985), Hansen \& Larsen (1992), Tomas (1996) and Song et al. (1999). Diatoms and dinoflagellates that have chloroplasts of their own were grouped as 'phytoplankton'. Ciliates and dinoflagellates that do not have their own chloroplasts were grouped as 'protozooplankton', even though some of them may contain functional chloroplasts. 
The dimensions of 10 cells of each taxa were measured and cell volumes were estimated from linear dimensions using simple volumetric formulae. Cellular carbon content was then calculated using the following equations (Menden-Deuer \& Lessard 2000) where $V$ is the cell volume:

Dinoflagellates: pgC cell ${ }^{-1}=0.760 \times V^{0.819}$

Diatoms > $3000 \mu^{3}$ : $p g C$ cell $^{-1}=0.288 \times V^{0.811}$

Other protists: $p g \mathrm{C} \mathrm{cell}^{-1}=0.216 \times V^{0.939}$

Although the water was pre-screened through a plankton net (mesh size $160 \mu \mathrm{m})$, some developmental stages of small copepods passed the filter. To evaluate their grazing impact on the protist community, the copepods were identified to species and developmental stage to estimate the clearance rate on potential prey examined in this paper. Enumeration and identification of copepods in some of the Lugol-fixed samples was conducted using a dissection microscope. The prosome length of each species was used for identification of the developmental stages. The maximum clearance was estimated for copepods using the equations given in Hansen et al. 1997 and taking size into consideration.

\section{RESULTS}

\section{pH and inorganic nutrients}

The $\mathrm{pH}$ of natural seawater samples was adjusted to pH 8, 8.5, 9 and 9.5 respectively, and kept stable by adjustments at each sampling occasion (Fig. 1). The incubations with $\mathrm{pH}$ levels between 8 and 9 showed a maximum reduction of $0.1 \mathrm{pH}$ units between sampling days. In the $\mathrm{pH} 9.5$ treatment, however, a reduction of $0.2 \mathrm{pH}$ units occurred between samplings, with 1 exception at Day 7 , where the reduction was $0.5 \mathrm{pH}$ units. The nutrient concentrations of $\mathrm{NH}_{4}{ }^{+}, \mathrm{NO}_{3}{ }^{-}$, $\mathrm{NO}_{2}{ }^{-}$and $\mathrm{PO}_{4}{ }^{2-}$ (Fig. 2) remained at the initial level in the $\mathrm{pH} 8$ to 9 incubations, with a slight decrease towards the end of the experiment. However, while the $\mathrm{pH} 9.5$ incubation experienced an increase in inorganic nutrients from the start of the experiment to the end, an exception was found for $\mathrm{PO}_{4}{ }^{2-}$, which decreased to the detection limit after Day 3. The concentration of $\mathrm{SiO}_{4}^{-}$in the $\mathrm{pH} 8$ and 8.5 incubations remained at a concentration of 2 to $6 \mu \mathrm{M}$ throughout the duration of the experiment (Fig. 2). In the $\mathrm{pH} 9$ incubation, the $\mathrm{SiO}_{4}{ }^{-}$concentration increased to a maximum of $12.5 \mu \mathrm{M}$ at Day 7 , whereafter it decreased to reach $9 \mu \mathrm{M}$ at Day 14. In the $\mathrm{pH} 9.5$ incubation, the $\mathrm{SiO}_{4}^{-}$kept increasing throughout the experiment to reach a maximum concentration of $31 \mu \mathrm{M}$ at Day 14.

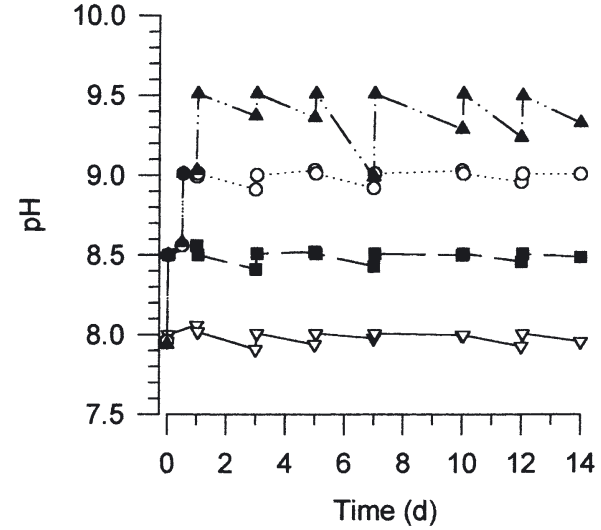

Fig. 1. $\mathrm{pH}$ fluctuations in the experimental bottles during the

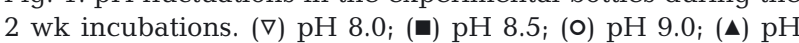
9.5. $\mathrm{pH}$ was adjusted at each sampling date to keep the $\mathrm{pH}$ constant

\section{The planktonic community}

Phytoplankton

The phytoplankton community was quantified in bulk using both chl a measurements and direct cell counts. The initial chl a concentration was $2.4 \mu \mathrm{g} \mathrm{l}^{-1}$ in all treatments (Fig. 3A). In the pH 8 to 9 incubations, the chl a concentration increased 2- to 3-fold during the first $10 \mathrm{~d}$. During the next $4 \mathrm{~d}$, the chl a concentration stabilised in the pH 8 and 8.5 incubations, whereas the $\mathrm{pH} 9$ incubation experienced a further 3-fold increase. In the pH 9.5 incubation, the chl a concentration declined more than $90 \%$ from Day 0 to 7 . However, at the termination of the experiment, the initial chl a concentration was almost regained.

The phytoplankton biomass (estimated from direct counts) was initially $53 \mu \mathrm{g} \mathrm{C} \mathrm{l}^{-1}$ (Fig. 3B). A general increase in biomass was observed in the $\mathrm{pH} 8$ and 8.5 incubations, increasing 3 - and 14 -fold, respectively. In the $\mathrm{pH} 9$ incubation, no increase was observed during the first week; however, during the last week, the biomass increased to reach the same level as found in the $\mathrm{pH} 8.5$ incubation. Unlike the other incubations, a significant decrease was observed in the pH 9.5 incubation during the first week. However, during the following week an increase to almost the initial biomass occurred.

The focus of the phytoplankton group was on diatoms and dinoflagellates because they were the most dominant classes in the present experiment (Fig. 3C,D). At the start of the incubations, the dinoflagellates dominated the phytoplankton community. However, during the 2 wk incubation, the relative importance of diatoms increased at all $\mathrm{pH}$ levels and they became dominant. At $\mathrm{pH} 8$ and 8.5, the diatoms 

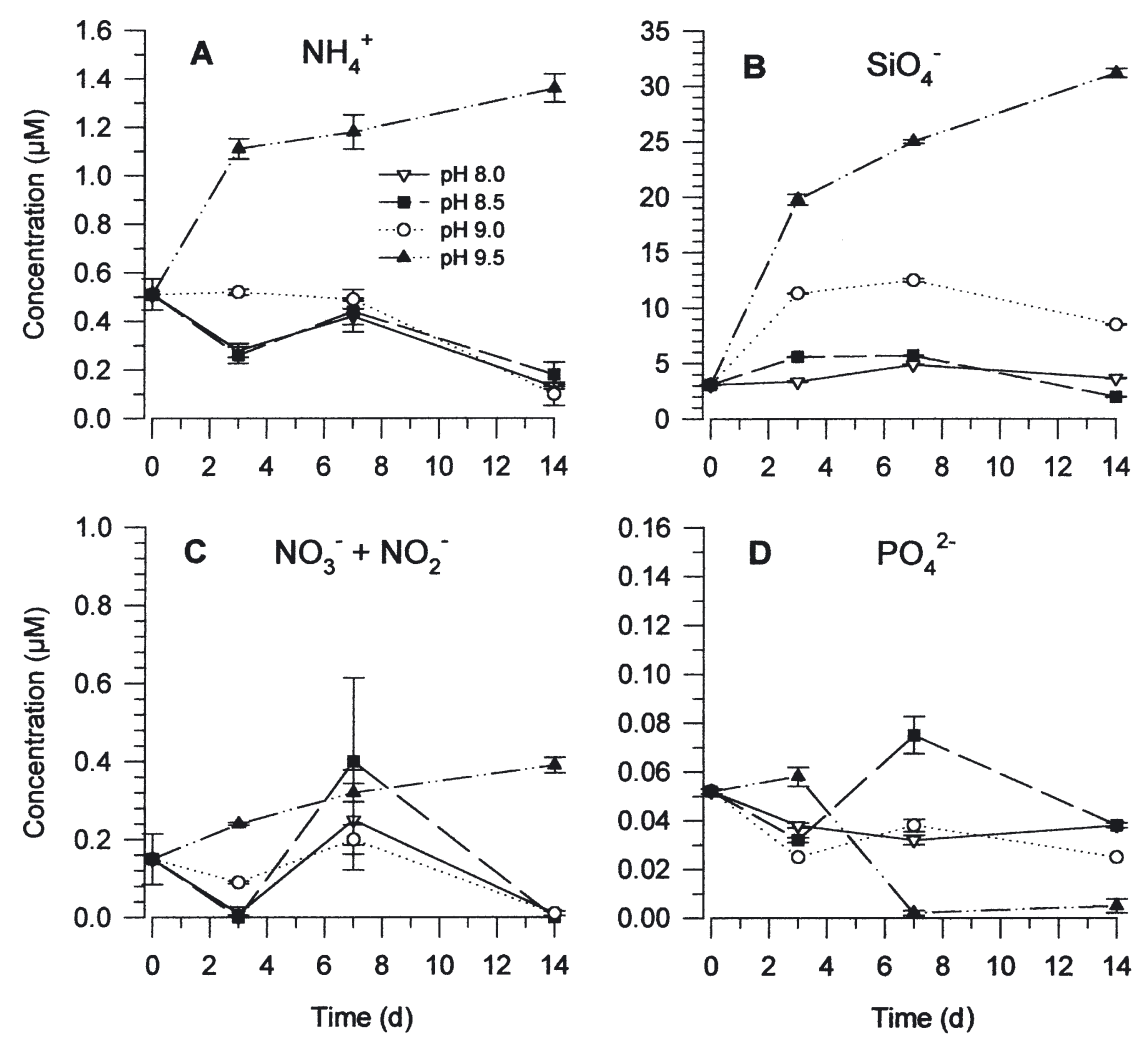

Fig. 2. Fluctuations in nutrient concentrations measured during the 2 wk experimental period. (A) $\mathrm{NH}_{4}^{+}$, (B) $\mathrm{SiO}_{4}^{-}$, (C) $\mathrm{NO}_{3}^{-}+$ $\mathrm{NO}_{2}{ }^{-}$, (D) $\mathrm{PO}_{4}{ }^{2-} .(\nabla) \mathrm{pH} 8.0$; ( $) \mathrm{pH}$

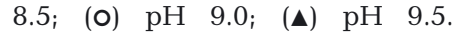
Symbols represent means of triplicates $\pm \mathrm{SE}$
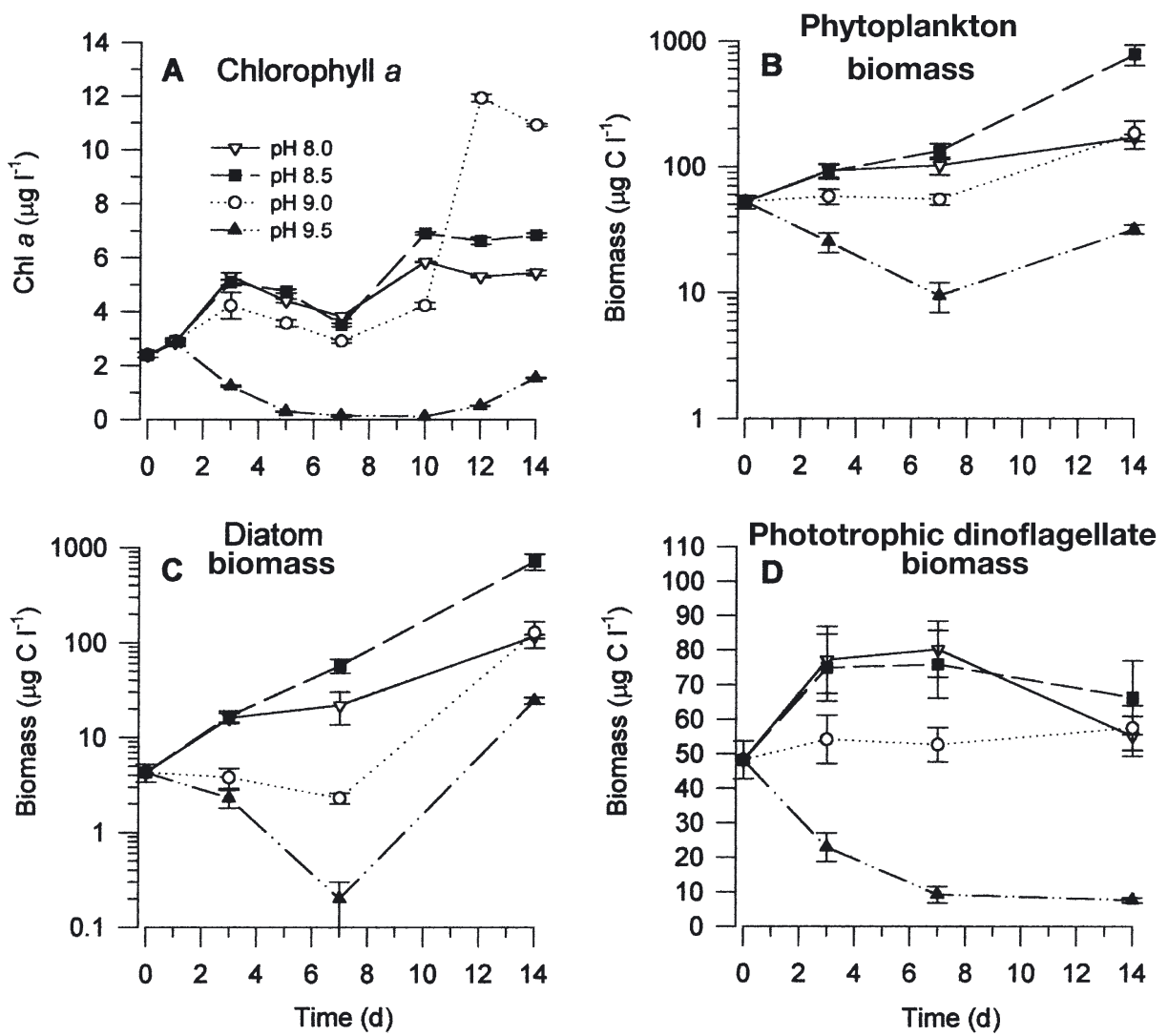

Fig. 3. Phytoplankton concentrations in the 4 incubations during the 2 wk experimental period. (A) Chlorophyll $a$, (B) phytoplankton biomass ( $\left.\mu \mathrm{g} \mathrm{C} \mathrm{l}^{-1}\right)$, (C) diatom biomass, (D) phototrophic dinoflagellate biomass. $(\nabla) \mathrm{pH}$ 8.0;

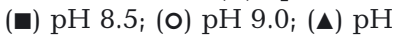
9.5. Symbols represent means of triplicates $\pm \mathrm{SE}$ 
grew throughout the duration of the experiment, whereas the dinoflagellates only grew for the first $3 \mathrm{~d}$. At higher $\mathrm{pH}$, the biomass of both diatoms and dinoflagellates either remained constant or declined during the first week of the incubation, and only growth of diatoms was observed during the second week of the incubations.

The succession among the species within the studied phytoplankton groups varied according to the $\mathrm{pH}$ level (Figs. 4 \& 5). The 2 lowest $\mathrm{pH}$ incubations, pH 8 and 8.5, experienced almost no succession among species. Here, all the identified species were present throughout the experimental period.

In the $\mathrm{pH} 9.5$ incubation, a pronounced succession of species occurred during the incubation period. At the end of the experiment, Cylindrotheca closterium was the only species among the diatoms that thrived. Its growth rate at $\mathrm{pH} 9.5$ was similar to the growth rates obtained in the lower $\mathrm{pH}$ incubations (Fig. 4, Table 1). Among the dinoflagellates, Prorocentrum micans, $P$. minimum and Heterocapsa triquetra all survived at pH 9.5, whereas the initial dominant species, Ceratium furca, C. fusus and C. tripos, died out (Fig. 5).

In the $\mathrm{pH} 9$ incubation, the succession of species was less pronounced, and only a few species died out. It was interesting to note however that some species apparently grew faster in the $\mathrm{pH} 9$ incubation compared to in the incubations at lower pH (Figs. 4 \& 5).

\section{Protozooplankton}

At the start of the experiment, the protozooplankton biomass was $20 \mu \mathrm{g} \mathrm{C}^{-1}$ in all incubations (Fig. 6A). In the $\mathrm{pH} 8,8.5$ and 9 incubations, a general increase in biomass was found over time. An 8-fold increase in biomass was observed at the termination of the experiment in the pH 8 and 9 incubations, whereas only a 3 -fold increase in biomass was found in the $\mathrm{pH} 8.5$ incubation. In the $\mathrm{pH} 9.5$ incubation, the biomass decreased about 5-fold during the first $3 \mathrm{~d}$ and stayed at that level until the termination of the experiment.

The increase in biomass in the $\mathrm{pH} 8,8.5$ and 9 incubations was mainly caused by ciliates, because the heterotrophic dinoflagellates were found to be relatively constant throughout the experiment. In the $\mathrm{pH} 9.5$ incubation, both ciliates and heterotrophic dinoflagellates declined in biomass throughout the duration of the experiment (Fig. 6B,C).

The succession among the species within the studied protozooplankton groups varied according to the $\mathrm{pH}$ level (Figs. $7 \& 8$ ). The 2 lowest $\mathrm{pH}$ incubations, $\mathrm{pH} 8$ and 8.5, experienced almost no succession among species. Here, all the identified species were present throughout the experimental period. In the $\mathrm{pH} 9.5$
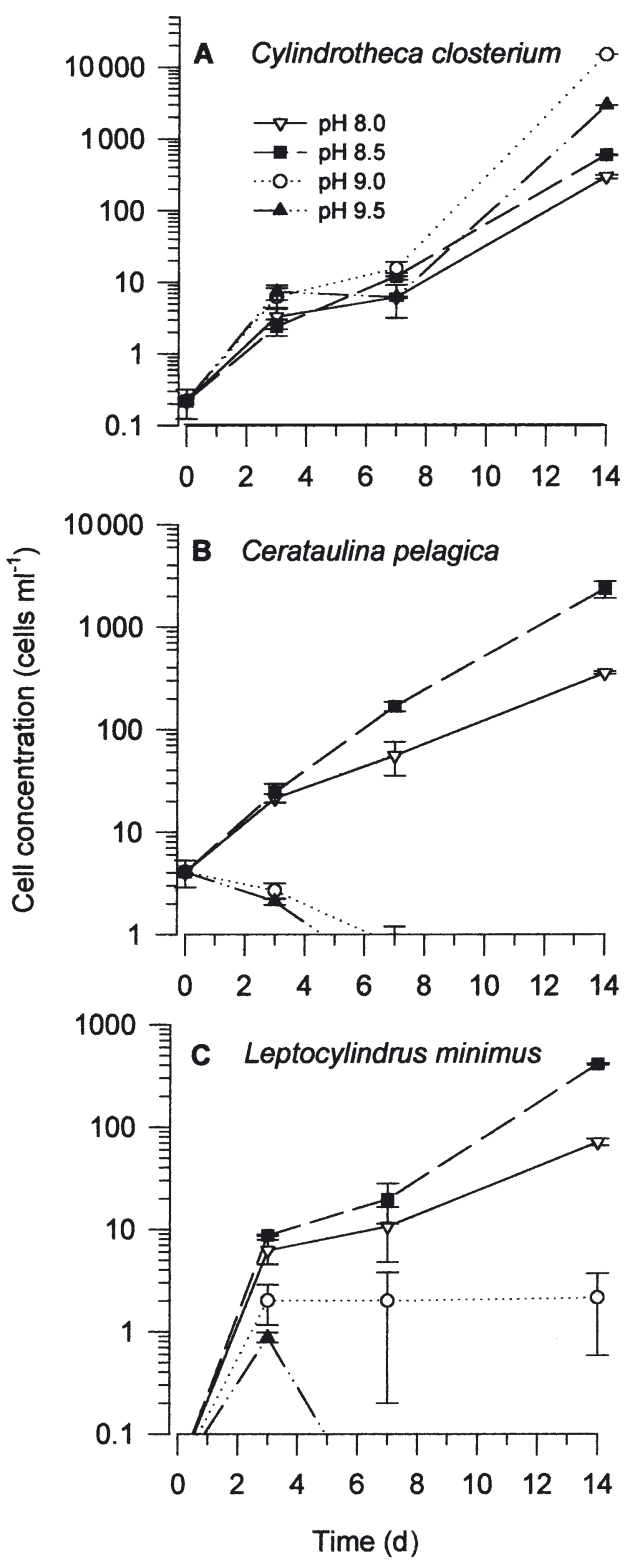

Fig. 4. Cell concentration of some selected diatoms in the 4 incubations during the $2 \mathrm{wk}$ experimental period. (A) Cylindrotheca closterium, (B) Cerataulina pelagica, (C) Leptocylin-

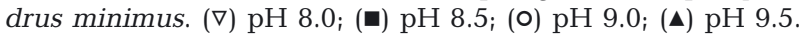

Symbols represent means of triplicates $\pm \mathrm{SE}$

incubation, some species died out, whereas the remaining species were alive at the termination of the experiment. However, unlike in the case of the phytoplankton, none of the protozooplankton species took over.

In the pH 9 incubation, the succession of species was less pronounced, and only a few species died out (Figs. 7 \& 8). It was interesting to note however that some ciliate species apparently grew faster in the $\mathrm{pH} 9$ incubation compared to in the incubations at lower $\mathrm{pH}$. 

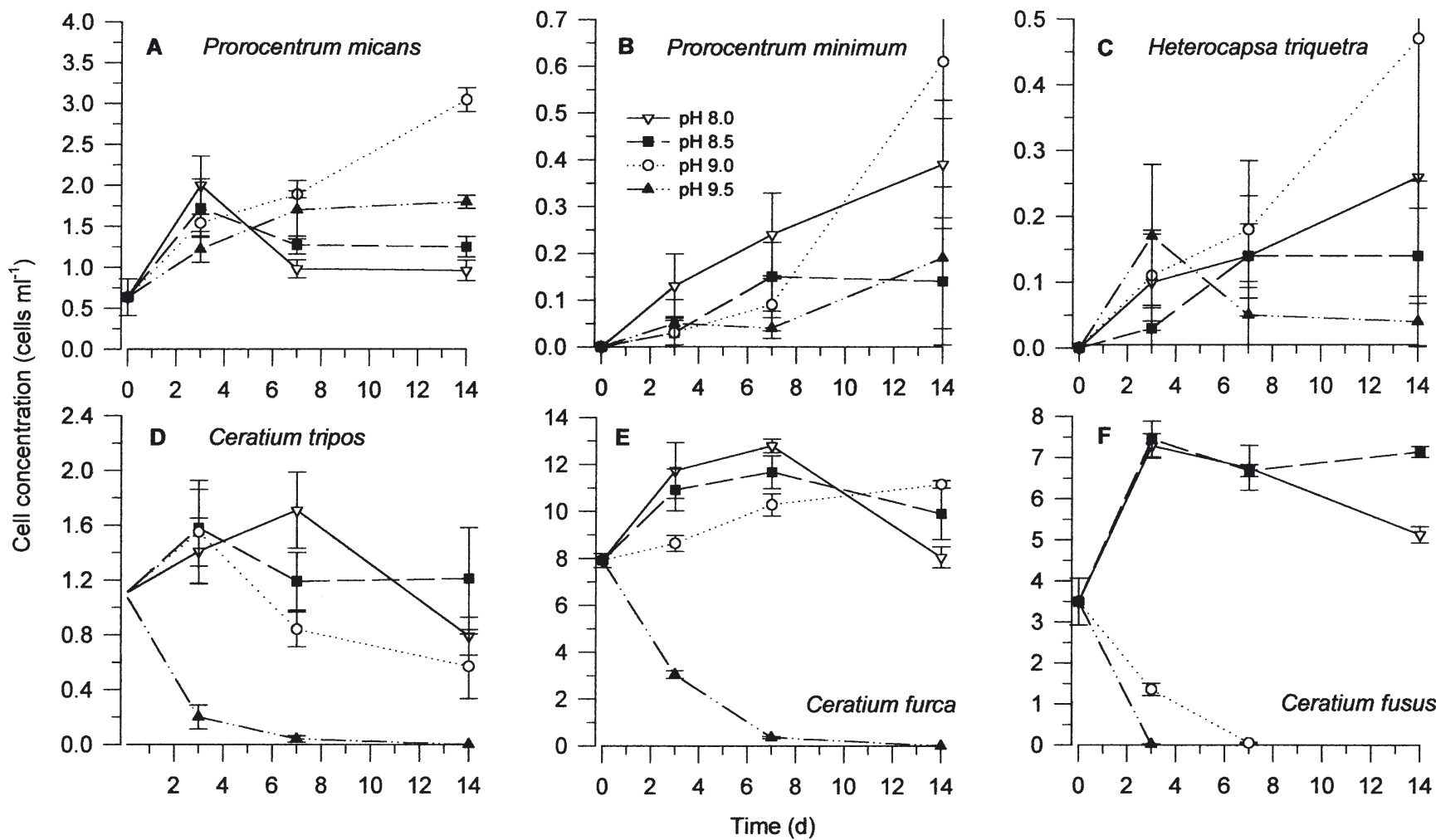

Fig. 5. Cell concentrations of selected phototrophic dinoflagellates in the 4 incubations during the 2 wk experimental period. (A) Prorocentrum micans, (B) P. minimum, (C) Heterocapsa triquetra, (D) Ceratium tripos, (E) Ceratium furca, (F) C. fusus. $(\nabla) \mathrm{pH} 8.0 ;(\mathbf{\square}) \mathrm{pH} 8.5 ;(0) \mathrm{pH} 9.0 ;(\boldsymbol{\Delta}) \mathrm{pH} 9.5$. Symbols represent means of triplicates $\pm \mathrm{SE}$

\section{Copepods}

In terms of numbers, the copepod community in the incubations consisted mainly of small Oithona spp. and only a few much larger copepods of the genera Pseudo-/Paracalanus spp. were found in the sample volumes studied. At the initiation of the experiment, a concentration of 84 copepods per litre were found, including all developmental stages. In the $\mathrm{pH} 8$ incubation, the number of copepods increased slightly during the experimental period, whereas a slight decrease was found at $\mathrm{pH}$ 8.5. No copepods were found in the pH 9 and 9.5 incubations after Days 5 and 0 , respectively (data not shown). Thus, the aver-

Table 1. Cylindrotheca closterium. Growth rate $\left(\mathrm{d}^{-1}\right)$ for the incubations $\mathrm{pH}$ 8.0, 8.5, 9.0 and 9.5

\begin{tabular}{|llll}
\hline pH & \multicolumn{3}{c}{ Growth rate $\left(\mathrm{d}^{-1}\right)$} \\
\cline { 2 - 4 } & Days 0 to 7 & Days 7 to 14 & Days 0 to 14 \\
\hline 8.0 & $0.54 \pm 0.07$ & $0.53 \pm 0.05$ & $0.54 \pm 0.05$ \\
8.5 & $0.62 \pm 0.09$ & $0.56 \pm 0.003$ & $0.56 \pm 0.04$ \\
9.0 & $0.65 \pm 0.07$ & $0.97 \pm 0.04$ & $0.81 \pm 0.02$ \\
9.5 & $0.48 \pm 0.06$ & $0.93 \pm 0.04$ & $0.70 \pm 0.05$ \\
\hline
\end{tabular}

age length and total calculated biomass increased over time only in the $\mathrm{pH} 8$ and 8.5 incubations (Figs. 9 \& 10).

The calculated maximum clearance for the $\mathrm{pH} 8$ and 8.5 incubations revealed that about $6 \%$ of the water was cleared daily at the start of the experiment. Considerable variation in calculated clearance was found and no consistent increase was observed during the experiment, probably due to the small sample sizes used. However, taking all data on clearance from the pH 8 and 8.5 incubations into consideration, the maximum and the average rate corresponded to a removal of 38 and $10 \%$ of the prey populations per day, respectively (Table 2).

\section{DISCUSSION}

\section{How did elevated pH affect the phytoplankton community?}

The phytoplankton communities incubated at $\mathrm{pH} 9$ and 9.5 clearly developed differently from those incubated at pH 8 and 8.5, with the most pronounced differences found at $\mathrm{pH} 9.5$ (Fig. 3). In the pH 9.5 incu- 
bation, a $75 \%$ decline in total phytoplankton biomass occurred during the first week. However, the effect was only transient, because the phytoplankton biomass increased again during the second week of incubation to $2 / 3$ of the initial phytoplankton biomass. The reason for this reduction in biomass was that some species declined in numbers or totally disappeared (Figs. 4 $\& 5)$. This resulted in a decline in the total number of algal taxa from 21 at the start of the experiment to a total of only 5 at the termination of the experiment, with only 1 species making up for $70 \%$ of the algal biomass (Figs. 3, 4 \& 11).

How do these results compare with laboratory data on single species? In a recent review, Hansen (2002) found that in laboratory cultures, only 7 out of a total of 35 phytoplankton species were able to grow at $\mathrm{pH}$ exceeding 9.5. Among species that had the capability of growing at high $\mathrm{pH}$ were the dinoflagellates Prorocentrum minimum and $P$. micans, which also were some of the ones growing in the $\mathrm{pH} 9.5$ incubation in the present experiment. Likewise, some of the species which during the incubation period disappeared or decreased in numbers in the $\mathrm{pH} 9$ and 9.5 incubations have been reported to be unable to grow at this high $\mathrm{pH}$. This is for instance the case for Ceratium tripos and C. lineatum, which are known for their sensitivity to high $\mathrm{pH}$, being unable to grow at $\mathrm{pH} 8.4$ and 8.7, respectively. The diatom Cylindrotheca closterium was the only species found to obtain a high growth rate in the pH 9.5 incubation (Fig. 4, Table 1). This diatom is known as a highly pH-tolerant species, which is able to sustain maximum growth up to $\mathrm{pH} 9.2$ in laboratory cultures (Barker 1935a, Grant et al. 1967, Humphrey \& Subba Rao 1967). Thus, in conclusion, there is good accordance between the observations made in the present study and the literature found on laboratory experiments concerning $\mathrm{pH}$ tolerances of phytoplankton.

\section{How did elevated $\mathrm{pH}$ affect the heterotrophic community?}

Elevated pH had a marked effect on both the protozooplankton and the copepod community. In the $\mathrm{pH} 9$ and 9.5 incubations, the development in terms of both biomass and species composition differed from the lower $\mathrm{pH}$ incubations. Many protozooplankton survived and even grew in the $\mathrm{pH} 9$ incubation, whereas only a few species survived the 2 wk exposure to $\mathrm{pH} 9.5$ (Figs. $6 \&$ 9). None of the copepod species was found to survive in the $\mathrm{pH} 9$ and 9.5 incubations for more than 5 and $1 \mathrm{~d}$, respectively, indicating that copepods are more sensitive to high $\mathrm{pH}$ than protozooplankton.

Our knowledge of how elevated pH affects the growth and survival of marine protozooplankton and
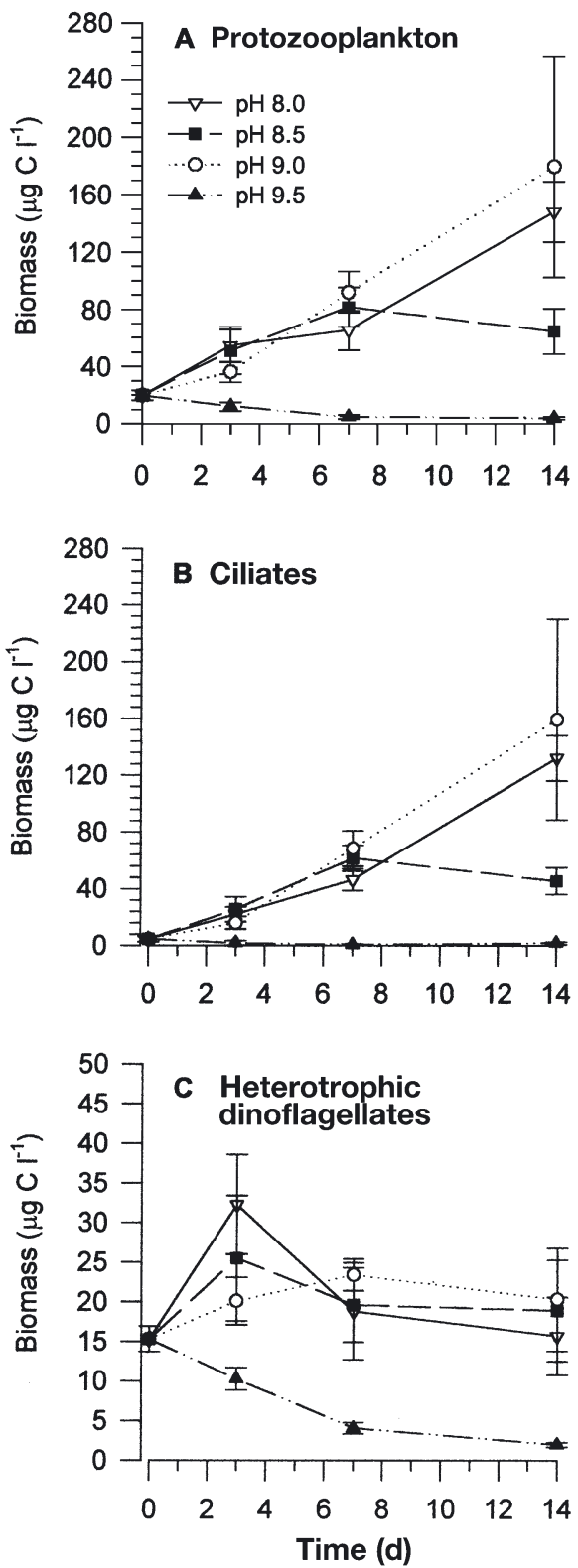

Fig. 6. Concentrations of protozooplankton in the 4 incubations during the 2 wk experimental period. (A) Total protozooplankton biomass, (B) ciliate biomass, (C) heterotrophic dinoflagellates biomass. ( $\nabla) \mathrm{pH} 8.0$; (匹) $\mathrm{pH} 8.5$; (O) $\mathrm{pH} 9.0$;

$(\boldsymbol{\Lambda}) \mathrm{pH}$ 9.5. Symbols represent means of triplicates $\pm \mathrm{SE}$

copepods is limited to a couple of laboratory studies on heterotrophic dinoflagellates and ciliates (Droop 1959, Pedersen \& Hansen 2003). In these studies, it was found that the heterotrophic dinoflagellate Oxyrrhis marina and the prostomatid ciliate Balanion comatum both were able to grow quite fast at a $\mathrm{pH}$ above 9.5, whereas the dinoflagellates Gyrodinium dominans and the ciliates Rimostrombidium caudatum, $R$. veniliae and Favella ehrenbergii had $\mathrm{pH}$ growth limits ranging 
from 8.8 to 9.3. When these organisms were exposed to higher $\mathrm{pH}$, they died out. Thus, the data we obtained from the incubation of field samples are not in conflict with the laboratory results and they point to the fact that elevated $\mathrm{pH}$ may cause species succession among heterotrophic organisms. The fact that we did not find any protozooplankton or copepod species that could respond to the increase in algal biomass in the $\mathrm{pH} 9.5$ incubation suggests that high $\mathrm{pH}$ may result in a reduction of the total grazing pressure on the natural phytoplankton community.

\section{Nutrient limitation and grazing effects}

The growth of the large-celled phototrophic dinoflagellates (e.g. Ceratium spp.) stopped after $3 \mathrm{~d}$ of incubation in the $\mathrm{pH} 8$ and 8.5 experiments, whereas small-celled phototrophic dinoflagellates and diatoms were able to grow throughout the experiment (Fig. 5). Thus, these large dinoflagellates were either subjected to a heavy grazing pressure or became nutrientlimited. Substantial grazing by the dominating copepods (cyclopoids) and ciliates on Ceratium spp. seems unlikely, simply because they cannot handle them (Hansen et al. 1994, Nielsen \& Kiørboe 1994). In the present study, the only potential grazers on the Ceratium spp. were the heterotrophic dinoflagellates, especially the Protoperidinium spp. (Hansen 1991, Buskey 1997, Naustvoll 2000), but their growth also stopped in the $\mathrm{pH} 8$ and 8.5 experiments after $3 \mathrm{~d}$ of incubation, indicating a very limited grazing pressure (Fig. 8).

The initial concentrations of inorganic nitrogen and phosphorus in the water in the present experiments were quite low, but close to Redfield's ratio of N:P 16:1. At the end of the experiments, this ratio had changed towards a ratio of 5:1 in the $\mathrm{pH} 8$ to 9 incubations, suggesting an inorganic nitrogen limitation. It is well known that smaller cells have lower half-saturation constants for nutrient uptake of inorganic nitrogen than large cells (e.g. Hein et al. 1995). This indicates that the most likely explanation for the lack of growth of Ceratium spp. was nutrient limitation, and that this apparently also affected their predators (see Lynn et al. 2000).

The $\mathrm{pH} 9.5$ incubation differed in respect to inorganic nutrient concentration from the other incubations (Fig. 2). At the end of the experiment, the $\mathrm{NH}_{4}{ }^{+}$concentration had increased 2- to 3-fold, whereas the phosphate concentration had decreased to almost detection level. The reason for the rapid increase in $\mathrm{NH}_{4}{ }^{+}$is undoubtedly due to a quick remineralisation of dead organisms, whereas the decrease in inorganic phosphorus is due to the much lower solubility of inorganic phosphorus at very high pH (Otsuki \& Wetzel 1972,

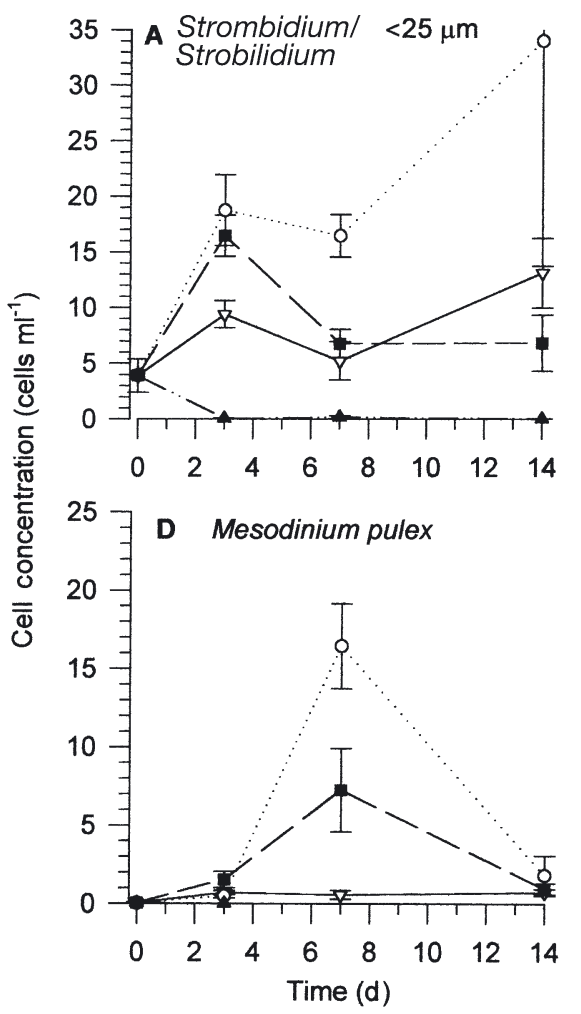

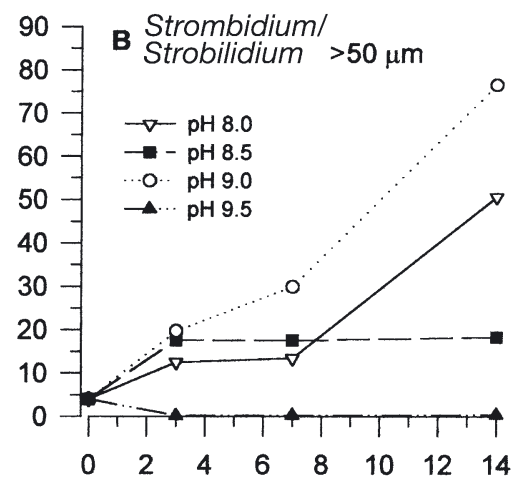

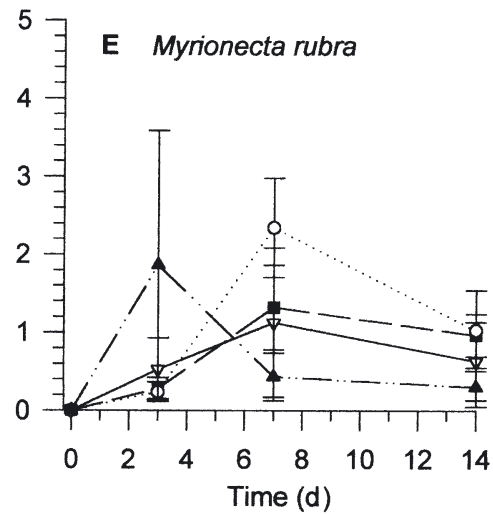

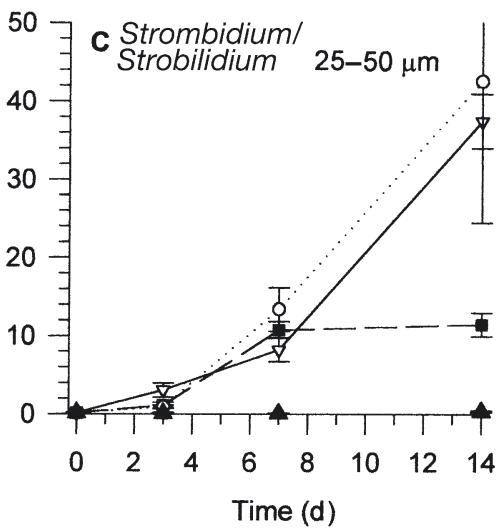

Fig. 7. Cell concentrations of selected ciliates in the 4 incubations during the 2 wk experimental period. (A) Strombidium/Strobilidium spp. $<25 \mu \mathrm{m}$, (B) Strombidium/Strobilidium spp. $>50 \mu \mathrm{m}$, (C) Strombidium/Strobilidium spp. 25 to $50 \mu \mathrm{m}$, (D) Mesodinium pulex, (E) Myrionecta rubra.

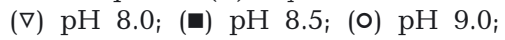
(৯) pH 9.5. Symbols represent means of triplicates $\pm \mathrm{SE}$ 
Kümmel 1981). This resulted in a potential phosphorus limitation of the phototrophic organisms, which may have affected the species composition. However, it is noteworthy that the growth rate of Cylindrotheca closterium was similar or even higher in the $\mathrm{pH} 9.5$ incubation compared to the rates found in lower $\mathrm{pH}$ incubations (Table 1). In fact, the highest growth rate of this diatom was found in the second week in the $\mathrm{pH} 9.5$
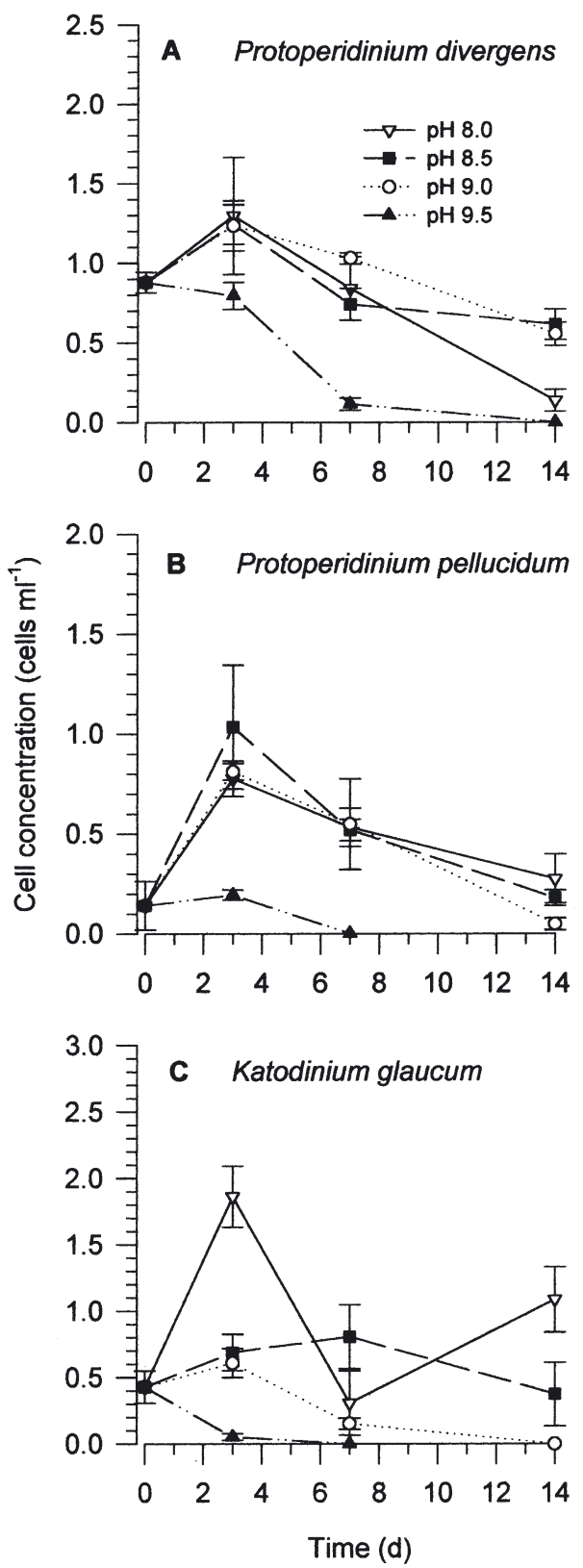

Fig. 8. Cell concentrations of selected heterotrophic dinoflagellates in the 4 incubations during the $2 \mathrm{wk}$ experimental period. (A) Protoperidinium divergens, (B) P. pellucidum, (C) Katodinium glaucum. ( $\nabla) \mathrm{pH} 8.0$; (ロ) $\mathrm{pH} 8.5$; () $\mathrm{pH} 9.0$; $(\boldsymbol{\Lambda}) \mathrm{pH}$ 9.5. Symbols represent means of triplicates $\pm \mathrm{SE}$
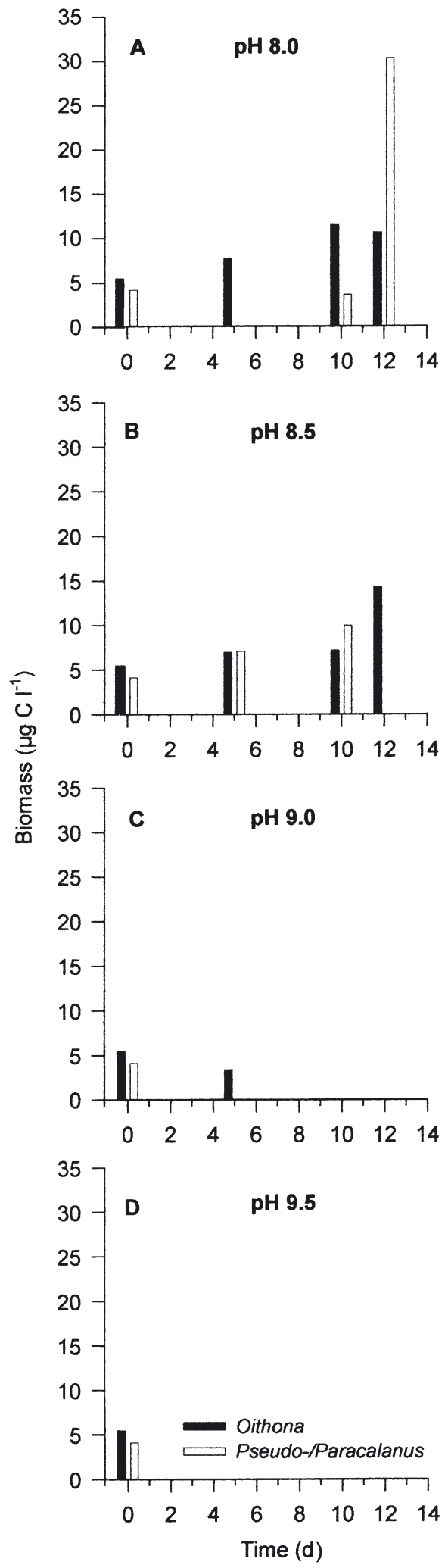

Fig. 9. Biomass of copepods (Oithona and Pseudo-/Paracalanus) in the 4 incubations during the $2 \mathrm{wk}$ experimental period. (A) $\mathrm{pH} 8.0$, (B) $\mathrm{pH} 8.5$, (C) $\mathrm{pH} 9.0$, (D) $\mathrm{pH} 9.5$ 


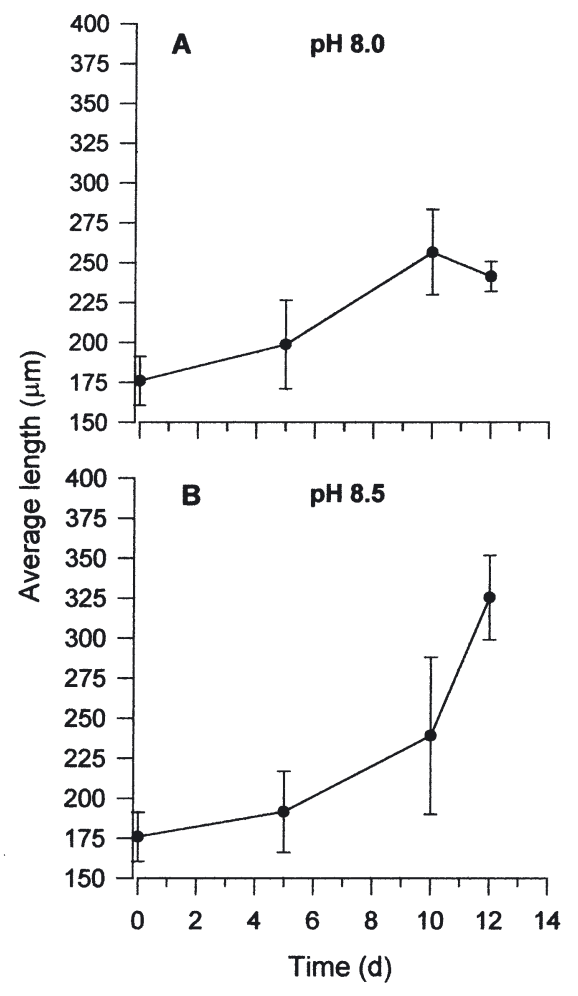

Fig. 10. Average size of the copepod Oithona in the 4 incubations during the 2 wk experimental period. (A) $\mathrm{pH} 8.0$,

(B) $\mathrm{pH}$ 8.5. Symbols represent means $\pm \mathrm{SE}$

incubation, where the phosphorus limitation should also have been the strongest (Fig. 2).

The silicate concentration was constant in the $\mathrm{pH} 8$ and 8.5 incubations throughout the duration of the experiment, and thus silicate does not seem to be limiting in these incubations (Fig. 2B). Dramatic increases in silicate concentration were however observed in the pH 9 and 9.5 incubations mainly during the first $3 \mathrm{~d}$ of the experiment. The largest increase in silicate concentration was found in the $\mathrm{pH} 9.5$ incubation, which reached a concentration of $\sim 30 \mu \mathrm{M}$ silicate at the termination of the incubation. This concentration is $\sim 3$ times higher than the maximum concentration of silicate typ-

Table 2. Estimated copepod clearance in percent of the total water volume per day for the incubations $\mathrm{pH}$ 8.0, 8.5, 9.0 and 9.5

\begin{tabular}{|ccccc|}
\hline \multirow{2}{*}{ pH } & \multicolumn{5}{c}{ Water volume cleared by the copepod community } \\
& Day 0 & Day 5 & Day 10 & Day 12 \\
\hline 8.0 & 5.8 & 1.2 & 6.1 & 37.9 \\
8.5 & 5.8 & 9.6 & 13.0 & 2.3 \\
9.0 & 5.8 & 0.5 & 0.0 & 0.0 \\
9.5 & 5.8 & 0.0 & 0.0 & 0.0 \\
\hline
\end{tabular}

ically found in the spring before the diatom bloom has started (Richardson \& Christoffersen 1991). The largest $\mathrm{pH}$ adjustments were done in the $\mathrm{pH} 9$ and 9.5 incubations, both at the initiation and during the experiment. It is therefore likely that we have added silicate along with the addition of $\mathrm{NaOH}$, because the $\mathrm{NaOH}$ solution was stored in glass bottles and it is well known that silicate is highly soluble at high $\mathrm{pH}$. The silicate concentration in the pH 9.5 incubation was, however, still much lower than what typically is added to ordinary algal growth media, like the $\mathrm{f} / 2$ medium (final concentration 100 to $200 \mu \mathrm{M}_{i}$ Guillard 1972). Thus, it does not seem likely that these high silicate concentrations should have had any negative impact on the algal species composition in the $\mathrm{pH} 9$ and 9.5 incubations.

The pH-tolerant species (Prorocentrum micans, $P$. minimum, Heterocapsa triquetra and Cylindrotheca closterium) did better in terms of growth in the $\mathrm{pH} 9$ incubation compared to the lower $\mathrm{pH}$ incubations (Figs. 4A \& 5A,B,C). This is in contrast to laboratory studies, which indicate that the growth rates of these species are reduced at $\mathrm{pH} 9$ compared to at $\mathrm{pH} 8$ (Schmidt \& Hansen 2001, Hansen 2002). Thus, the reason for the better growth of these species in the $\mathrm{pH} 9$ could instead be reduced grazing.

Among the potential grazers, only ciliates and copepods occur in such numbers that they potentially may play a role as grazers on the $4 \mathrm{pH}$-tolerant species. Significant predation due to the ciliates can however be ruled out. First, none of them can ingest the long diatom Cylindrotheca closterium, and only the large $(>50 \mu \mathrm{m})$ ciliates can ingest dinoflagellates as large as Heterocapsa triquetra and Prorocentrum minimum (e.g. Hansen et al. 1994). Second, the number of the

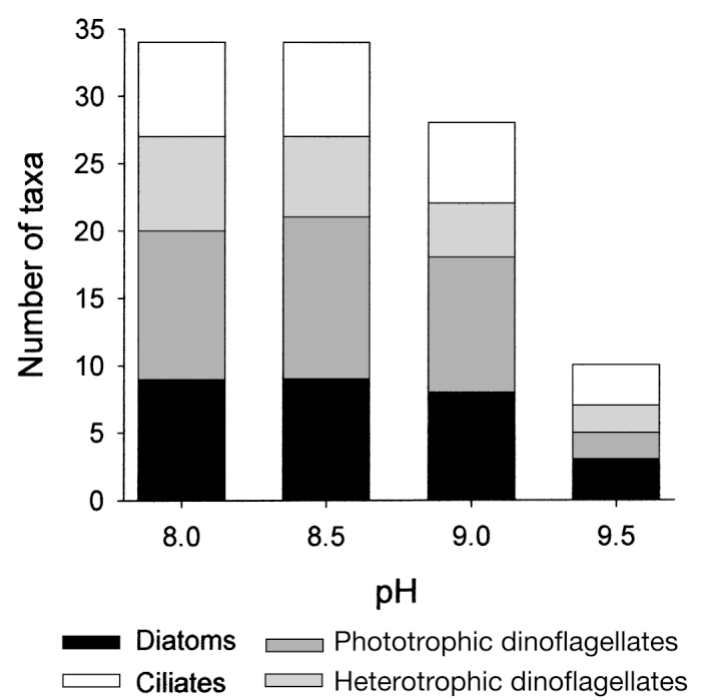

Fig. 11. Number of taxa (species or size groups) found at Day 14 in concentrations $>0.1$ cells ml ${ }^{-1}$ 
large ciliates was actually highest in the $\mathrm{pH} 9$ incubation, compared to the incubations at lower $\mathrm{pH}$, and thus the grazing loss due to these ciliates should have been the largest in the pH 9 incubation (Fig. 7).

The dominant copepods (cyclopids) found in the incubations have the potential to feed on all the $\mathrm{pH}$ tolerant phytoplankton (Hansen et al. 1994, Nielsen \& Kiørboe 1994). Therefore, a significant grazing impact by the copepods on these algal populations may have occurred in the $\mathrm{pH} 8$ and 8.5 incubations. Our estimates suggest that the copepods may have been able to remove about $10 \%$ of the standing phytoplankton stock per day (Table 2). Thus, the loss of grazing by copepods in the pH 9 incubation is a likely explanation for the observed better net growth of the $\mathrm{pH}$-dominant phytoplankton, but the remineralisation of dying $\mathrm{pH}-$ sensitive phytoplankton has probably also contributed.

Copepods including cyclopoids can also easily feed on ciliates (Stoecker \& Capuzzo 1990, Nielsen \& Sabatini 1996, Nakamura \& Turner 1997), and thus it is highly likely that the better net growth of ciliates at $\mathrm{pH} 9$ can be explained, at least partly, by copepod grazing on the ciliates in the $\mathrm{pH} 8$ and 8.5 incubations (Table 2). However, we did not count the small-sized protists $(<10 \mu \mathrm{m})$, which are the preferred prey for most planktonic ciliates (Jonsson 1986, Fenchel 1987). Thus, the better growth of ciliates in the pH 9 incubation could also have been due to either increased prey concentration or to a shift in prey species composition.

\section{Possible effects of elevated pH on natural ecosystems}

Our results demonstrate that the exposure of a natural plankton community to high $\mathrm{pH}$ for extended periods of time (several days to weeks) will result in a significant decrease in species richness of both phototrophic and heterotrophic organisms. At present, we can say only little about how short-term (hours) $\mathrm{pH}$ changes may affect species composition of marine planktonic ecosystems. At $\mathrm{pH}$ below 8.5 , short-term $\mathrm{pH}$ changes will not have any effects. However, the exposure to very high $\mathrm{pH}$ (9 to 9.5) may kill some protozooplankton and copepod species within $24 \mathrm{~h}$ (present study, Pedersen \& Hansen 2003).

In our experiments, Cylindrotheca closterium became the dominant phytoplankton species. However, in nature, it is rarely diatoms but more often dinoflagellates which tend to dominate during periods of high pH (Yoo 1991, Hinga 1992, Macedo et al. 2001, Olesen 2001, Hansen 2002). An explanation for the different succession pattern found in nature and in the present experiments could be that most dinoflagellate blooms occur during calm sunny weather conditions
(Taylor \& Pollingher 1987). Under such conditions, diatoms will sink out as a consequence of their lack of motility. In our experiments, however, the algal population was kept suspended allowing the growth of diatoms.

Our results also indicate that the copepod community and a great deal of the protozooplankton community are killed when $\mathrm{pH}$ approaches 9, suggesting at least a temporal release of grazing pressure on the phytoplankton. Thus, a release of grazing pressure on the phytoplankton will potentially allow them to grow even denser, thereby further increasing the $\mathrm{pH}$. A consequence of such a scenario is that ecosystems experiencing periods with elevated $\mathrm{pH}$ may potentially experience algal blooms for extended periods of time.

The effects of elevated $\mathrm{pH}$ on the planktonic community in nature will, however, very much depend on the duration of the exposure to high $\mathrm{pH}$ and the extent to which plankton species can be reintroduced. Thus, enclosed water bodies, which for extended periods are subjected to elevated $\mathrm{pH}$, will have low species richness of both phototrophic and heterotrophic organisms. The reason for this is simply that the $\mathrm{pH}$ in such a system either is high throughout the year or that the system cannot regain lost species in periods when the $\mathrm{pH}$ is within the normal range of 8 to 8.2. Data from natural systems of this kind are virtually non-existent. However, a survey made in a Portuguese eutrophic lagoon on phytoplankton exemplifies that such systems do exist. This lagoon has a $\mathrm{pH}$ above 8.8 all year round and a very low phytoplankton species richness. The almost constant mono-specific blooms that occur in this area are due to either diatoms, e.g. Cylindrotheca closterium, or more often the dinoflagellate Prorocentrum minimum (Macedo et al. 2001). Thus, enclosed ecosystems characterized by permanently high $\mathrm{pH}$ seem to be similar to other extreme environments like saline lakes and acidic mining lakes, which are ecosystems that also are characterised by reduced species richness (Kalff \& Watson 1986, Williams et al. 1990, Packroff 2000, Pedrozo et al. 2001, Kalff 2002).

In coastal areas like bays and fjords, which also may experience elevated $\mathrm{pH}$ for extended periods, the species richness of the plankton communities will only temporarily be affected. As soon as the surface water is mixed with water from adjacent areas or the water column is mixed due to storms, the system will shift back to higher species richness. An example of such a system is Mariager Fjord, Denmark, which is a eutrophic semi-enclosed system. This fjord experiences elevated $\mathrm{pH}$ from May to August every year with the maximum $\mathrm{pH}$ often exceeding 9. During these periods, the fjord is characterised by very dense almost mono-specific blooms. The blooms consist of either the dinoflagellates Heterocapsa triquetra and Prorocentrum mini- 
mum, the diatom Skeletonema costatum or the cleptoplastidic ciliate Myrionecta rubra (Fenchel et al. 1995). During the rest of the year, the phytoplankton community is much more diverse.

In conclusion, the present experiments with the exposure of a planktonic community to a fixed $\mathrm{pH}$ show that an increase in $\mathrm{pH}$ kills $\mathrm{pH}$-sensitive organisms and causes a decrease in the species richness of both phototrophic and heterotrophic organisms. Our results indicate that the response of an ecosystem to an elevated $\mathrm{pH}$ very much depends upon the duration of the exposure. Our results also suggest that copepods are quite sensitive to elevated $\mathrm{pH}$ compared to protozooplankton. In their absence, phytoplankton is only subjected to grazing from the other protists. This will favour phytoplankton species that have developed grazing-resistant mechanisms such as toxin production, poor food quality or shape.

Acknowledgements. We are indebted to Christian Marc Andersen for analyzing the metazooplankton samples and to Torkel Gissel Nielsen for valuable comments and suggestions to the paper. We also thank Benni Winding Hansen for the kind use of his fluorometer. The work was funded by both the Danish Natural Research Council (project \#9801391 \& \#21-010539) and the European Commission's Environment \& Sustainable Development (ESD) (FP-V, research into the development of Sustainable Marine Ecosystems, Key action 3) under contract EVK3-CT-1999-00015 BIOHAB (Biological Control of Harmful Algal Blooms in European coastal waters).

\section{LITERATURE CITED}

Barker HA (1935a) Photosynthesis in diatoms. Arch Mikrobiol 6:141-156

Barker HA (1935b) The culture and physiology of the marine dinoflagellates. Arch Mikrobiol 6:157-181

Brussaard CPD, Gast GJ, van Duyl FC, Riegman R (1996) Impact of phytoplankton bloom magnitude on a pelagic microbial food web. Mar Ecol Prog Ser 144:211-221

Buskey EJ (1997) Behavioral components of feeding selectivity of the heterotrophic dinoflagellate Protoperidinium pellucidum. Mar Ecol Prog Ser 153:77-89

Dodge JD (1985) Marine dinoflagellates of the British Isles. Her Majesty's Stationary Office, London

Droop MR (1959) A note on some physical conditions for cultivating Oxyrrhis marina. J Mar Biol Assoc UK 38:599-604

Elzenga JTM, Hidde BA Prins, Stefels J (2000) The role of extracellular carbonic anhydrase activity in inorganic carbon utilization of Phaeocystis globosa (Prymnesiophyceae): a comparison with other marine phytoplankton using the isotopic disequilibrium technique. Limnol Oceanogr 45:372-380

Fenchel T (1987) Ecology of protozoa: the biology of freeliving phagotrophic protists. Springer-Verlag, Berlin

Fenchel T, Bernard C, Esteban G, Finlay BJ, Hansen PJ, Iversen $N$ (1995) Microbial diversity and activity in a Danish fjord with anoxic deep water. Ophelia 43:45-100

Gnaiger E, Gluth G, Weiser W (1978) pH fluctuations in an intertidal beach in Bermuda. Limnol Oceanogr 23: 851-857
Goldman JC, Yossef A, Riley CB, Dennett MR (1982) The effect of $\mathrm{pH}$ in intense microalgal cultures. II. Species competition. J Exp Mar Ecol 57:15-24

Grant BR, Madgwick J, Dal Pont G (1967) Growth of Cylindrotheca closterium var. californica (Mereschk.) Reimann \& Lewin on nitrate, ammonia and urea. Aust J Mar Freshw Res 18:129-136

Grasshoff K (1976) Methods of seawater analysis. Verlag Chemie, Weinheim

Guillard RRL (1972) Culture of phytoplankton for feeding marine invertebrates. In: Smith WL, Chanley $\mathrm{MH}$ (eds) Culture of marine invertebrate animals. Plenum Press, New York, p 29-60

Hansen B, Bjørnsen PK, Hansen PJ (1994) Prey size selection in planktonic zooplankton. Limnol Oceanogr 39:395-403

Hansen G, Larsen J (1992) Dinoflagellater i danske farvande. In: Thomsen HA (ed) Plankton i de indre danske farvande. Havforskning fra Miljøstyrelsen Nr. 11. Miljøministeriet, København, p 45-155

Hansen PJ (1991) Quantitative importance and trophic role of heterotrophic dinoflagellates in a coastal pelagical food web. Mar Ecol Prog Ser 73:253-261

Hansen PJ (2002) The effect of high pH on the growth and survival of marine phytoplankton: implications for species succession. Aquat Microb Ecol 28:279-288

Hansen PJ, Hansen B, Bjørnsen PK (1997) Zooplankton grazing and growth: scaling within the size range 2 to $2000 \mu \mathrm{m}$. Limnol Oceanogr 42:687-704

Hein M, Pedersen MF, Sand-Jensen K (1995) Size-dependent nitrogen uptake in micro- and macrophytoplankton. Mar Ecol Prog Ser 118:247-253

Hinga KR (1992) Co-occurrence of dinoflagellate blooms and high $\mathrm{pH}$ in marine enclosures. Mar Ecol Prog Ser 86: 181-187

Hinga KR (2002) Effects of pH on coastal marine phytoplankton. Mar Ecol Prog Ser 238:281-300

Humphrey GF, Subba Rao DV (1967) Photosynthetic rate of the marine diatom Cylindrotheca closterium. Aust J Mar Freshw Res 18:123-127

Jonsson PR (1986) Particle size selection, feeding rates and growth dynamics of marine planktonic oligotrichous ciliates (Ciliophora: Oligotrichina). Mar Ecol Prog Ser 33:265-277

Kalff J (2002) Inland water ecosystems. Prentice-Hall, Englewood Cliffs, NJ

Kalff J, Watson S (1986) Phytoplankton and its dynamics in two tropical lakes: a tropical and temperate zone comparison. Hydrobiologia 138:161-176

Kümmel R (1981) Zur Phosphateliminierung durch Fällung mit Calciumionen. Acta Hydrochim Hydrobiol 9:585-588

Lynn SG, Kilham SS, Kreeger DA, Interlandi SJ (2000) Effects of nutrient availability on the biochemical and elemental stoichiometry in the freshwater diatom Stephanodiscus minutulus (Bacillariophyceae). J Phycol 36:510-522

Macedo MF, Duarte P, Mendes P, Ferreira G (2001) Annual variation of environmental variables, phytoplankton species composition and photosynthetic parameters in a coastal lagoon. J Plankton Res 23:719-732

Menden-Deuer S, Lessard EJ (2000) Carbon to volume relationships for dinoflagellates, diatoms, and other protist plankton. Limnol Oceanogr 45:569-579

Nakamura Y, Turner JT (1997) Predation and respiration by the small cyclopoid copepod Oithona similis: how important is feeding on ciliates and heterotrophic flagellates? J Plankton Res 19:1275-1288

Naustvoll LJ (2000) Prey size spectra and food preferences in thecate heterotrophic dinoflagellates. Phycologia 39: 187-198 
Nielsen TG, Kiørboe T (1994) Regulation of zooplankton biomass production in a temperate, coastal ecosystem. 1. Copepods. Limnol Oceanogr 39:493-507

Nielsen TG, Sabatini M (1996) Role of cyclopoid copepods Oithona spp. in North Sea plankton communities. Mar Ecol Prog Ser 139:79-93

Nimer NA, Brownlee C, Merret MJ (1994) Carbon dioxide availability, intracellular $\mathrm{pH}$ and growth of the coccolithophore Emiliania huxleyi. Mar Ecol Prog Ser 109:257-262

Olesen M (2001) Sedimentation in Mariager Fjord, Denmark: the impact of sinking velocity on system productivity. Ophelia 55:11-26

Otsuki A, Wetzel RG (1972) Coprecipitation of phosphate with carbonates in a marl lake. Limnol Oceanogr 17: $763-767$

Packroff G (2000) Protozooplankton in acidic mining lakes with special respect to ciliates. Hydrobiologia 433:157-166

Pedersen MF, Hansen PJ (2003) Effects of high pH on the growth and survival of six marine heterotrophic protists. Mar Ecol Prog Ser 260:33-41

Pedrozo F, Kelly L, Diaz M, Temporetti P and 6 others (2001) First results on the water chemistry, phytoplankton and trophic status of an Andean acidic lake system of volcanic origin in Patagonia (Lake Caviahue). Hydrobiologia 452: 129-137

Richardsen K, Christoffersen A (1991) Seasonal distribution and production of phytoplankton in the southern Kattegat. Mar Ecol Prog Ser 78:217-227

Editorial responsibility: Otto Kinne (Editor),

Oldendorf/Luhe, Germany
Santhanam R, Srinivasan A, Ramadhas V, Devaraj M (1994) Impact of Trichodesmium bloom on the plankton and productivity in the Tuticorin bay, southeast coast of India. Indian J Mar Sci 23:27-30

Schmidt LE, Hansen PJ (2001) Allelopathy in the prymnesiophyte Chrysochromulina polylepis: effect of cell concentration, growth phase and pH. Mar Ecol Prog Ser 216:67-81

Song W, Mingzhuang Z, Chen Z (1999) Updating the systematics of the planktonic oligotrichous ciliates (Ciliophora, Protozoa) with description of ciliature patterns at generic level. The Yellow Sea 5:77-85

Stoecker DK, Capuzzo JM (1990) Predation on protozoa: its importance to zooplankton. J Plankton Res 12:891-908

Taylor FJR, Pollingher U (1987) Ecology of dinoflagellates. In: Taylor FJR (ed) The biology of dinoflagellates. Botanical monographs. Blackwell Scientific Publications, Oxford, p 399-529

ter Braak CJF, van Dam H (1989) Inferring $\mathrm{pH}$ from diatoms: a comparison of old and new calibration methods. Hydrobiologia 178:209-223

Tomas CR (1996) Identifying marine diatoms and dinoflagellates. Academic Press, San Diego, CA

Williams WD, Boulton AJ, Taaffe RG (1990) Salinity as determinant of salt lake fauna: a question of scale. Hydrobiologia 197:257-266

Yoo KI (1991) Population dynamics of dinoflagellate community in Masan Bay with a note on the impact of environmental parameters. Mar Pollut Bull 23:185-188

Submitted: July 9, 2002; Accepted: June 17, 2003

Proofs received from author(s): September 15, 2003 